\title{
Nutrient Retention, Nutrient Limitation, AND SEDIMENT-NutRIENT INTERACTIONS in a Pasture-Dominated Stream
}

\author{
I. Chaubey, D. Sahoo, B. E. Haggard，M. D. Matlock，T. A. Costello
}

\begin{abstract}
Even though agricultural land use is a principal source of nonpoint-source pollution, the in-stream movement and transport of nutrients and their interaction with benthic sediments are not well understood. The objectives of this study were to: (1) assess if nutrients were limiting algal growth, (2) assess equilibrium between sediments and water column phosphorus $(P)$, (3) evaluate spatial and temporal variability in $P$ buffering capacity and easily exchangeable $P$, and (4) evaluate variations in stream nutrient retention efficiency in Moore's Creek, a pasture-dominated watershed in northwest Arkansas. This study used nutrient limitation bioassays, sediment nutrient extractions, and short-term nutrient injections to accomplish the study objectives. Results suggested that light, not nutrients, was limiting algal growth in Moore's Creek. Sediment equilibrium $P$ concentration measurements suggested that sediments may be releasing dissolved inorganic $P$ during winter and spring; however, sediments were a potential temporary sink of dissolved inorganic $P$ during summer and fall. Exchangeable $P$ concentrations varied between 0.4 and $1.0 \mathrm{mg} \mathrm{kg}^{-1}$ of dry sediments, and $P$ sorption index varied between 3.2 and 5. Concentrations of ammonia nitrogen $\left(\mathrm{NH}_{4}-\mathrm{N}\right)$ and ortho $\mathrm{P}\left(\mathrm{PO}_{4}-\mathrm{P}\right)$ generally decreased between sampling stations during nutrient injections at all three sites; however, nitrate $N\left(\mathrm{NO}_{3}-\mathrm{N}\right)$ concentrations increased downstream. A significant retention of $\mathrm{NO}_{3}-\mathrm{N}$ was not observed in any of the experiments, indicating that agricultural headwater streams may be a source of downstream $\mathrm{NO}_{3}-\mathrm{N}$ transport. The results indicated that a riparian cover should be maintained in nutrient-rich headwater streams in order to minimize algal production in the streams. Even nutrient-rich streams may continue to assimilate, to some extent, increased loads of $P$, altering the timing and magnitude of downstream transport of $P$.
\end{abstract}

Keywords. Limitation, Nutrient retention, Sediment interaction, Water quality.

A quatic systems have an intrinsic ability to assimilate nutrients and have a capacity to sustain a certain degree of nutrient loading. When nutrient loading in a stream exceeds its assimilative capacity, water becomes eutrophic, resulting in reduced nutrient retention efficiency of the stream. Retention, cycling, and export of nutrients from watersheds are greatly influenced by processes occurring within a stream (Meyer and Likens, 1979). Nutrient retention efficiency indicates the rate at which nutrients cycle between the dissolved state in the water column, benthic sediments, and biota of the stream (Stream Solute Workshop, 1990).

Submitted for review in July 2005 as manuscript number SW 5973; approved for publication by the Soil \& Water Division of ASABE in November 2006. Presented at the 2003 ASAE Annual Meeting as Paper No. 032281 .

The authors are Indrajeet Chaubey, ASABE Member, Associate Professor, Department of Agricultural and Biological Engineering, Purdue University, West Lafayette, IN; Debabrata Sahoo, ASABE Member Engineer, Graduate Student, Department of Biological and Agricultural Engineering, Texas A\&M University, College Station, Texas; and Brian E. Haggard, Associate Professor, Marty D. Matlock, Associate Professor, and Thomas A. Costello, ASABE Member Engineer, Associate Professor, Department of Biological and Agricultural Engineering, University of Arkansas, Fayetteville, Arkansas. Corresponding author: Indrajeet Chaubey, 225 South University Street, West Lafayette, IN 47907-2093; phone: 765-494-1134; fax 765-496-1115; e-mail: ichaubey@ purdue.edu.
Downstream transport of nutrients during base flow conditions is affected by microbial uptake and abiotic sorption. When a nutrient travels downstream, it may cycle from the dissolved inorganic form in the water column to the particulate form and back to the water column in dissolved inorganic form. The number of nutrient cycles within a given stream reach depends on the spiraling length $(S)$, the downstream distance required to complete a nutrient cycle (Elwood et al., 1983). Spiraling length is the summation of uptake length $\left(S_{w}\right)$ and turnover length $\left(S_{B}\right)$ and indicates nutrient retention efficiency of the stream (Marti and Sabater, 1996); $S_{w}$ is the distance a nutrient molecule travels in dissolved inorganic form before it is taken up from the water column, and $S_{B}$ is the distance a nutrient molecule travels in particulate form before it is released in inorganic form to the water column. $S_{w}$ is a major component of $S$, generally constituting greater than $90 \%$ of the $S$ (Newbold et al., 1983; Stream Solute Workshop, 1990). Measurement of $S_{w}$ can be used to assess the nutrient retention efficiency of the stream (Meyer et al., 1999). The value of $S_{w}$ has been shown to depend on stream hydrologic properties such as velocity and flow depth (Stream Solute Workshop, 1990). Davis and Minshall (1999) argued that the mass transfer coefficient $\left(v_{f}\right)$, calculated as a function of $S_{w}$, stream flow, and velocity, should be used to compare nutrient dynamics in streams that have different hydrologic properties. Various abiotic and biotic processes have been shown to influence the values of $S_{w}$ and $v_{f}$ in streams (Klotz, 1988; Elwood et al., 1981; Lock et al., 1990). 
Sorption of nutrients by benthic sediments is an abiotic process that may influence nutrient retention in streams, especially P. Benthic sediments have been shown to influence the water column P concentrations by adsorption or desorption in aquatic systems (Klotz, 1988; Meyer, 1979) and may buffer increasing P loads in streams (Haggard et al., 1999).

Water column $\mathrm{P}$ and benthic sediment interactions can be quantified using the $\mathrm{P}$ sorption index (PSI) and sediment equilibrium $\mathrm{P}$ concentration $\left(\mathrm{EPC}_{0}\right)$. The PSI is unitless and is a single-point measurement of the ability of sediments to adsorb P (Bache and Williams, 1971). Sediment $\mathrm{EPC}_{0}$ is the concentration of the dissolved $\mathrm{P}$ in the water column when the net sorption on sediments is negligible (Klotz, 1988). When water column $\mathrm{P}$ is greater than sediment $\mathrm{EPC}_{0}$, sediments may temporarily store $\mathrm{P}$ by adsorbing water column $\mathrm{P}$, whereas if the water column $\mathrm{P}$ is less than sediment $\mathrm{EPC}_{0}$, sediments may release $\mathrm{P}$ to the water column (House et al., 1995; Meyer, 1979). However, abiotic processes are not the only mechanism by which nutrients are retained in streams; Haggard et al. (1999) reported that $38 \%$ of the $\mathrm{P}$ retention in streams could be attributed to biotic processes.

When biotic processes, such as microbial and algae uptake of nutrients, are important, the limiting nutrient may be efficiently retained in the stream. Generally, the ratio of $\mathrm{N}$ to $\mathrm{P}$ gives some indication of the limiting nutrient in the system (Redfield, 1958; Allan, 1995); however, nutrient concentrations in the system can be great enough that nutrient limitation does not occur. The presence of various forms of $\mathrm{N}$ and $\mathrm{P}$, including nitrate $\mathrm{N}\left(\mathrm{NO}_{3}-\mathrm{N}\right)$, ammonia $\mathrm{N},\left(\mathrm{NH}_{4}-\mathrm{N}\right)$, dissolved inorganic $\mathrm{P}$ (DIP), dissolved organic $\mathrm{P}$ (DOP), and particulate organic $\mathrm{P}$ (POP), in an aquatic system makes it difficult for predicting the actual limiting nutrient strictly from an N:P ratio (Morris and Lewis, 1988). In addition, factors such as micronutrients or light may be limiting periphyton growth (Wold and Hershey, 1999). A biological assessment of limiting nutrients can help identify the relationship between nutrient availability and algal growth.

Even though agricultural land use has been identified as the principal contributor of nonpoint-source (NPS) pollution (Sharpley et al., 1994), most studies in agricultural catchments have focused on measurement and modeling of the import of nutrients to the stream environments (Sharpley et al., 2002, 2001). Very few studies have assessed the movement and transport of nutrients within the stream ecosystems, especially in pasture-dominated watersheds (Haggard et al., 2001; Macrae et al., 2003). Most studies of nutrient transport and retention have been conducted in nutrient-depleted headwaters such as forested streams and desert streams (D’Angelo at al., 1991; Meyer, 1979; Newbold et al., 1983; Grimm, 1987; Grimm and Fisher, 1986). Understanding solute dynamics and various in-stream processes in pasture-dominated streams may help develop watershed management plans for NPS pollution and provide insight into better ecological management practices in the watershed.

The goal of this study was to assess nutrient-limiting algal growth, sediment-nutrient interactions, and nutrient retention efficiency in Moore's Creek, a stream impacted primarily by pasture land use. The objectives of this study were to: (1) assess if nutrients were limiting algal growth, (2) assess equilibrium between sediments and water column $\mathrm{P}$, (3) evaluate spatial and temporal variability in P buffering capacity and easily exchangeable P, and (4) evaluate variation in stream nutrient retention efficiency using short-term nutrient additions.

\section{Study Site Description}

Nutrient injections, sediment extractions, and periphytometer deployment and harvesting were conducted at site 1 (most upstream site), site 2 (middle site), and site 3 (most downstream site) in Moore's Creek during June 2002 and January, March, and June 2003 (fig. 1). Moore's Creek is a spring-fed second-order stream that is a part of the Illinois River basin in northwest Arkansas. The headwater streams of the Illinois River basin have alluvial gravel, riffle-pool geomorphology (Brussock et al., 1985). Streams substrates in this river basin are dominated by limestone, sandstone, and shales and have a karst topography.

The drainage area of Moore's Creek is approximately 2,120 ha (Vendrell et al., 1997). The major land uses in the watershed are pasture (62\%), forest $(26 \%)$, and urban $(7 \%)$. Cotter (2002) reported that the watershed had 10 active poultry houses and 13 inactive poultry houses with an annual manure application rate $5,600 \mathrm{~kg} \mathrm{ha}^{-1}$ pasture in the watershed. Excessive land application of animal manure in the watershed has led to degradation of surface and ground water caused by runoff of $\mathrm{N}$ and $\mathrm{P}$, sediments, and pathogens (Edwards et al., 1996).

The presence or absence of trees differentiated the riparian area of the three study sites. Site 1 had negligible riparian forest and was dominated by pasture land use and cattle grazing on both sides of the stream, whereas the downstream sites had riparian areas dominated by tall trees such as sycamore, river birch, black willow, osage orange, and black walnut ranging in width from 30 to $500 \mathrm{~m}$. Mean tree height in the study sites was $20 \mathrm{~m}$. The percent canopy cover at these sites ranged from less than $10 \%$ at site 1 to about $60 \%$ at site 3 .

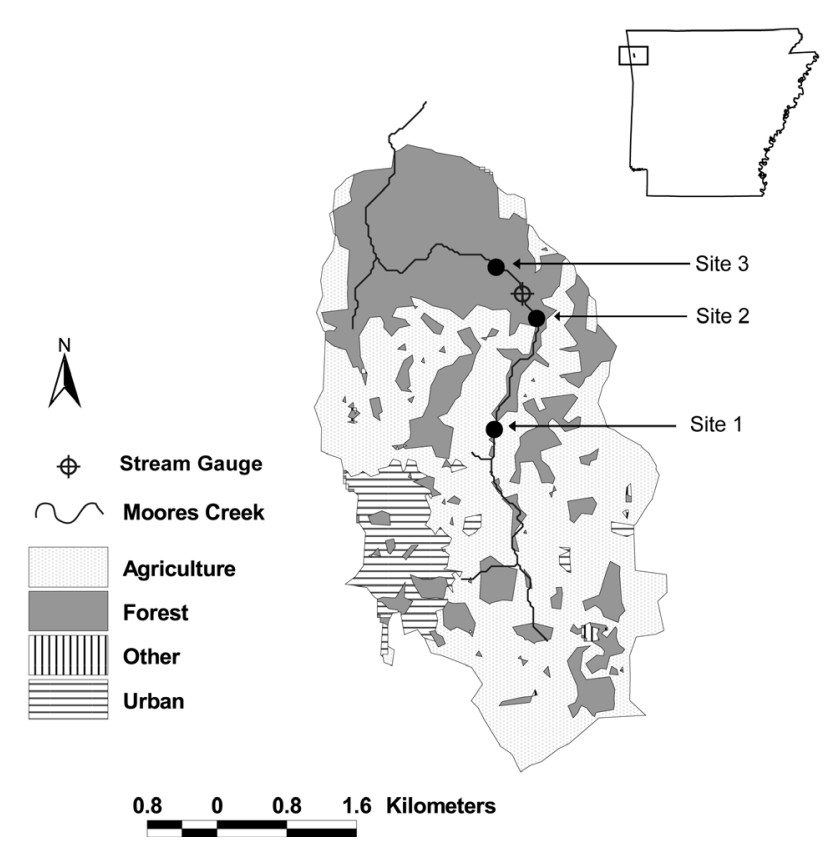

Figure 1. Moore's Creek watershed with location of stream gauge and stream reaches used in this study. 


\section{Materials ANd Methods}

\section{Algal Nutrient Limitation}

Nutrient limitation to algal growth was assessed at all three sites by deploying passive diffusion periphytometers (Matlock et al., 1998) for 15 days each in June 2002, January 2003, March 2003, and June 2003. In order to test the hypothesis that lack of light was limiting the response of periphyton to nutrient enrichment, an additional periphytometer was deployed upstream from site 1 in June 2003 in a stream segment devoid of any riparian trees (i.e., no shade). The passive diffusion periphytometers were constructed with $1.52 \times 1.52 \mathrm{~m}$ utility cattle panel $(4 \mathrm{~mm}$ welded wire $)$. Pontoons were constructed of $1.52 \mathrm{~m}$ lengths of $10 \mathrm{~cm}$ PVC pipe, with end caps glued on both sides. Two pontoons per raft were attached using stainless steel hose clamps. The pontoons floated the rack near the stream-atmosphere interface.

Forty bottles (HDPE, $250 \mathrm{~mL}$ ) were used as reservoirs containing the treatment nutrients. The four treatments, each with ten replicates, were: (1) $2 \mathrm{mg} \mathrm{L}^{-1}$ of $\mathrm{PO}_{4}-\mathrm{P}$ from $\mathrm{NaH}_{2} \mathrm{PO} 4 \cdot 7 \mathrm{H}_{2} \mathrm{O}$ (treatment P), (2) $20 \mathrm{mg} \mathrm{L}^{-1}$ of $\mathrm{NO}_{3}-\mathrm{N}$ from $\mathrm{NaNO}_{3}$ (treatment $\mathrm{N}$ ), (3) $2 \mathrm{mg} \mathrm{L} \mathrm{L}^{-1}$ of $\mathrm{PO}_{4}-\mathrm{P}$ from $\mathrm{NaH}_{2} \mathrm{PO}_{4} \cdot 7 \mathrm{H}_{2} \mathrm{O}$ plus $20 \mathrm{mg} \mathrm{L}-1$ of $\mathrm{NO}_{3}-\mathrm{N}$ from $\mathrm{NaNO}_{3}$ (treatment $\mathrm{N}+\mathrm{P}$ ), and (4) distilled water (control treatment). The treatment concentrations were 10 to 20 times greater than the ambient nutrient concentration in the stream, as suggested by Matlock et al. (1998). The treatments were put in marked bottles, and the bottle openings were covered by nylon membrane ( $47 \mathrm{~mm}$ diameter, $0.45 \mu \mathrm{m}$ pore size) and a glass fiber filter (42.5 mm, Whatman 934-AH). An aluminum screen (household variety, $300 \times 300 \mathrm{~mm}$ square mesh) covered the top of the bottles and growth substrate to prevent grazing of the algae by macroinvertebrates or vertebrates (such as fish). The bottles were arranged on the rack following a randomized block design with eight treatments per block arranged in five rows.

Stream water samples were collected during the period of deployment. Three replicates of approximately $250 \mathrm{~mL}$ of unfiltered water were collected in HDPE bottles for $\mathrm{NO}_{3}-\mathrm{N}$ analysis, and approximately $40 \mathrm{~mL}$ of filtered water $(0.45 \mu \mathrm{m})$ was collected in glass vials using HDPE syringes for $\mathrm{PO}_{4}-\mathrm{P}$ analysis.

When periphytometers were harvested, the glass fiber filters were carefully removed from the bottle and stored in pre-labeled glass vials with $5 \mathrm{~mL}$ of aqueous acetone saturated with magnesium carbonate, wrapped in aluminum foil, and kept in the dark on ice until returned to the laboratory. After returning to the laboratory, the samples were frozen until analyzed. All samples were analyzed for chlorophyll-a (Chl-a) using the trichromatic method (APHA, 1998) using a spectrophotometer (Spectronic Genesys 2).

\section{SEDiment Extractions}

Sediment samples were collected during the first week of the periphytometer deployment. At each site, about $2 \mathrm{~L}$ of unfiltered stream water, $250 \mathrm{~mL}$ of unfiltered stream water, and about $20 \mathrm{~mL}$ of filtered stream water were collected from the middle of the stream perpendicular to the flow direction. Stream discharge, $\mathrm{pH}$, temperature, conductivity, salinity, and dissolved oxygen were measured at each of the sediment-sampling stations. At each site, three transects perpendicular to the flow direction were established. Benthic sediments were collected from the top 2 to $5 \mathrm{~cm}$ of streambed using a trowel along each transect and were kept in plastic bags. Three replicates $(n=3)$ of sediment and water samples were collected at each site. The sediment and water samples were stored in the dark on ice until transported to the laboratory. The water samples were analyzed for $\mathrm{NO}_{3}-\mathrm{N}$, $\mathrm{NH}_{4}-\mathrm{N}$, total Kjeldahl N (TKN), $\mathrm{PO}_{4}-\mathrm{P}$, and total $\mathrm{P}(\mathrm{TP})$.

Immediately after return to the laboratory, the sediments samples were sieved using a $4.76 \mathrm{~mm}$ sieve, and the fraction of sediments less than $4.76 \mathrm{~mm}$ was used in the extractions to determine sediment $\mathrm{EPC}_{0}$, PSI, and exchangeable $\mathrm{P}$ (Ex-P) concentration.

To measure sediment $\mathrm{EPC}_{0}, 100 \mathrm{~mL}$ of filtered $(0.45 \mu \mathrm{m})$ stream water was spiked with additional $\mathrm{PO}_{4}-\mathrm{P}(0,0.05,0.1$, and $\left.0.2 \mathrm{mg} \mathrm{L}^{-1} \mathrm{PO}_{4}-\mathrm{P}\right)$ and added to approximately $25 \mathrm{~g}$ of fresh, wet sediment. The sediment solution was shaken for $1 \mathrm{~h}$ in a reciprocating shaker at $100 \mathrm{rpm}$. The sediment solution was also vigorously shaken manually every $15 \mathrm{~min}$. After $1 \mathrm{~h}$, the sediment solution was removed from the shaker, and sediments were allowed to settle for $30 \mathrm{~min}$. About 15 to $20 \mathrm{~mL}$ of the supernatant was filtered into pre-labeled $20 \mathrm{~mL}$ scintillation vials using a vacuum filtering unit and nylon filter membranes $(0.45 \mu \mathrm{m}$, Nylaflo nylon membrane). The aliquots were stored at $4^{\circ} \mathrm{C}$ until analyzed for $\mathrm{PO}_{4}-\mathrm{P}$ concentration. The remaining sediment slurry was transferred to pre-weighed, pre-labeled aluminum pans and dried for $48 \mathrm{~h}$ at $80^{\circ} \mathrm{C}$ in an oven to determine sediment dry mass. Sediment $\mathrm{EPC}_{0}$ was estimated as the $x$-intercept of the regression line with $\mathrm{PO}_{4}-\mathrm{P}$ concentration as independent variable and the amount of $\mathrm{P}$ sorbed as dependent variable (Klotz, 1988).

The PSI was determined by adding $100 \mathrm{~mL}$ of filtered stream water spiked with an additional $2 \mathrm{mg} \mathrm{L}^{-1}$ of $\mathrm{PO}_{4}-\mathrm{P}$ solution (Bache and Williams, 1971). About 20 to $30 \mathrm{~g}$ of fresh, wet sediments was added to $100 \mathrm{~mL}$ of the aqueous solution. Sediment extraction methods were similar to $\mathrm{EPC}_{0}$ sediment extraction. The PSI was calculated as:

$$
\text { PSI }=\frac{X}{\log C}
$$

where $X$ is the amount of $\mathrm{PO}_{4}-\mathrm{P}$ adsorbed ( $\mathrm{mg} \mathrm{kg}^{-1}$ dry sediments) from the initial concentration of $2 \mathrm{mg} \mathrm{L}^{-1}$, and $C$ is the final nutrient concentration $\left(\mathrm{mg} \mathrm{L}^{-1}\right)$ in solution after $1 \mathrm{~h}$.

Exchangeable $\mathrm{P}(\mathrm{Ex}-\mathrm{P})$ is a conservative estimate of easily available $\mathrm{P}$ for release from benthic sediment to the water column. Ex-P was determined by adding about 20 to $30 \mathrm{~g}$ of fresh sediments to $100 \mathrm{~mL}$ of $1 \mathrm{M} \mathrm{MgCl}_{2}$ (Ruttenburg, 1992). Sediment extraction methods were similar to sediment $\mathrm{EPC}_{0}$ extractions. The exchangeable nutrient concentration was determined as mg nutrient $\mathrm{kg}^{-1}$ dry sediment:

$$
\text { Ex }-\mathrm{P}=\frac{\text { mg nutrient } \mathrm{L}^{-1 *} 0.1 \mathrm{~L}}{\text { dry sediment mass }}
$$

\section{SHORT-Term NutriENT INJECTION}

Nutrient injections were conducted during the second week of the periphytometer deployment. At each study site, a reach length of approximately $100 \mathrm{~m}$ was selected, and five sampling stations were marked within the reach length. Three $250 \mathrm{~mL}$ background water samples along a transect perpendicular to the flow direction, and downstream of a riffle, were collected at each sampling site immediately 
before the start of each injection. First, the water samples were collected at the most downstream sampling station, followed sequentially by the next upstream station. The three collected unfiltered water samples were composited, and a $250 \mathrm{~mL}$ unfiltered water sample and a $50 \mathrm{~mL}$ of composite filtered sample were subsequently collected. Water samples were filtered using a $25 \mathrm{~mm}, 0.45 \mu \mathrm{m}$ nylon membrane (Nylaflo nylon membrane, Cole-Parmer) and HDPE syringes. All water samples were stored in the dark and on ice until returned to the laboratory.

A Mariotte bottle was used for nutrient injection. Nitrogen in the form of $\mathrm{NH}_{4} \mathrm{NO}_{3}, \mathrm{P}$ in the form of $\mathrm{Na}_{2} \mathrm{HPO}_{4}$, and $\mathrm{Cl}^{-}$ in the form of $\mathrm{NaCl}$ were used in the nutrient injection solution. $\mathrm{Cl}^{-}$was used as a conservative solute (tracer) for dilution correction. The desired changes in concentration above ambient concentration for added $\mathrm{PO}_{4}-\mathrm{P}, \mathrm{NO}_{3}-\mathrm{N}$, and $\mathrm{NH}_{4}-\mathrm{N}$ at Moore's Creek were 0.03, 0.1, and $0.1 \mathrm{mg} \mathrm{L}^{-1}$, respectively. The amount of solute in the solution was calculated using the required concentration, the flow rate of the stream, and the injection rate. The Mariotte bottle emitter was calibrated to allow a flow of $0.002 \mathrm{~L} \mathrm{~s}^{-1}$. The stream flow was measured one day before the injection and was used to calculate the required solute concentration.

Each injection was started approximately 10:30 a.m. Conductivity was measured at 1 min intervals at the most upstream sampling station and the most downstream sampling station using 115 A Plus Orion and YSI conductivity meters. Once the conductivity reached plateau at the most downstream sampling station, water samples were collected at the five sampling stations using the methods discussed previously and the injection was stopped. Conductivity was measured at $1 \mathrm{~min}$ intervals at the last sampling station until it decreased to background conditions. Properties such as water depth, stream width, and cross-sectional area were measured at ten different transects spaced uniformly within each study reach. Stream velocity and depth measurements were taken at $0.3 \mathrm{~m}$ stream width increment at the first and last sampling stations after the short-term nutrient injections. Stream discharge was estimated as a product of stream cross-sectional area and velocity (Hauer and Lamberti, 1996).

Nutrient concentrations during injections were corrected for background concentrations, and $\mathrm{Cl}^{-}$was used for dilution correction of groundwater inflow. In order to estimate the uptake length, the corrected nutrient concentration $\left(C_{x}\right)$ at each sampling station was divided by the corrected nutrient concentration at the first station $\left(C_{0}\right)$ and regressed against distance $(x)$ downstream from first sampling station:

$$
\begin{gathered}
C_{x}=C_{0} * e^{-k x} \\
\ln \left(\frac{C_{x}}{C_{0}}\right)=-k x
\end{gathered}
$$

where $k$ is the nutrient uptake coefficient $\left(\mathrm{m}^{-1}\right)$, and the nutrient uptake length $\left(S_{w}\right)$ was estimated as the inverse of $k$. The value of $S_{w}$ was estimated only when regression between $\ln \left(C_{x} / C_{0}\right)$ and $x$ was significant $(\mathrm{p}<0.1)$.

The mass transfer coefficient $\left(v_{f}, \mathrm{~m} \mathrm{~s}^{-1}\right)$ for nutrients was calculated as follows (Davis and Minshall, 1999):

$$
v_{f}=\frac{v^{*} d}{S_{w}}
$$

where $v$ is water velocity $\left(\mathrm{m} \mathrm{s}^{-1}\right), d$ is mean water depth (m), and $S_{w}$ is uptake length (m). The value of $v_{f}$ represents the velocity at which nutrients in the water column move toward benthic sediments and quantifies the demand for nutrients relative to the supply in the water column (Hall et al., 2002).

\section{Water Quality ANalysis}

The collected water samples were delivered to the Arkansas Water Resources Center Water Quality Laboratory for analysis of $\mathrm{NO}_{3}-\mathrm{N}, \mathrm{NH}_{4}-\mathrm{N}, \mathrm{TKN}, \mathrm{PO}_{4}-\mathrm{P}$, and TP. $\mathrm{NO}_{3}-\mathrm{N}$ was analyzed by the ion chromatography method (EPA-300-0), $\mathrm{NH}_{4}-\mathrm{N}$ and TKN were analyzed by the salicylate method (EPA-351-2), TP was analyzed by the sulfuric acid-nitric acid digestion method followed by ascorbic acid reduction (4500 P-B; APHA, 1998), and $\mathrm{PO}_{4}-\mathrm{P}$ was analyzed by the ascorbic acid reduction method (EPA $365.2)$. The total number of replicates $(n)$ analyzed for each parameter was 11.

\section{Statistical Analysis}

Effects of nutrient enrichment ( $\mathrm{N}, \mathrm{P}$, and $\mathrm{N}+\mathrm{P}$ as treatment variables) on Chl-a production as a response variable were analyzed using Tukey's test for between-subjects factorial analyses of variance (Sheskin, 2000). A single-factor analysis of variance was performed to assess if statistically significant differences existed among sediment $\mathrm{EPC}_{0}$ values across sites and seasons, and to compare mean differences between sediment $\mathrm{EPC}_{0}$ and $\mathrm{PO}_{4}-\mathrm{P}$ concentrations (Sheskin, 2000). Similarly, a single-factor analysis of variance was performed to compare mean differences in Ex-P concentrations among study sites and seasons. In all statistical analyses performed, the data were assumed to be normally distributed and the level of significance $(\alpha)$ used was 0.1 .

\section{Results ANd Discussions WATER QuALITY}

Baseflow water quality data showed spatial and temporal variations in nutrient concentrations in Moore's Creek (figs. 2 and 3). $\mathrm{NH}_{4}-\mathrm{N}$ concentration varied between $<0.01$ (below detection limit) to $0.07 \mathrm{mg} \mathrm{L}^{-1}$ on all sampling dates. There was a distinct temporal difference in average ambient $\mathrm{NH}_{4}-\mathrm{N}$ concentration in Moore's Creek $(\mathrm{p}=0.0001)$, where the concentration was greatest in high-temperature months (June 2002 and June 2003) and below detection limits in low-temperature months (January 2003 and March 2003) (fig. 2). Mineralization rates in stream water may have been relatively less during winter (January 2003) compared to summer, limiting $\mathrm{NH}_{4}-\mathrm{N}$ detection in water samples. Measured $\mathrm{NH}_{4}-\mathrm{N}$ concentrations were greatest at site 1 compared to sites 2 and $3(\mathrm{p}=0.002)$ during June 2002 (fig. 2). However, concentrations were not statistically different between the sites during January 2003, March 2003, and June 2003 experiments.

Average $\mathrm{NO}_{3}-\mathrm{N}$ concentration varied between 0.22 and $0.83 \mathrm{mg} \mathrm{L}^{-1}$ on all sampling dates (fig. 2). A distinct temporal variation $(\mathrm{p}=0.01)$ in average $\mathrm{NO}_{3}-\mathrm{N}$ concentration was observed, where $\mathrm{NO}_{3}-\mathrm{N}$ concentrations were greater during winter (January 2003) and spring (March 2003) and least 

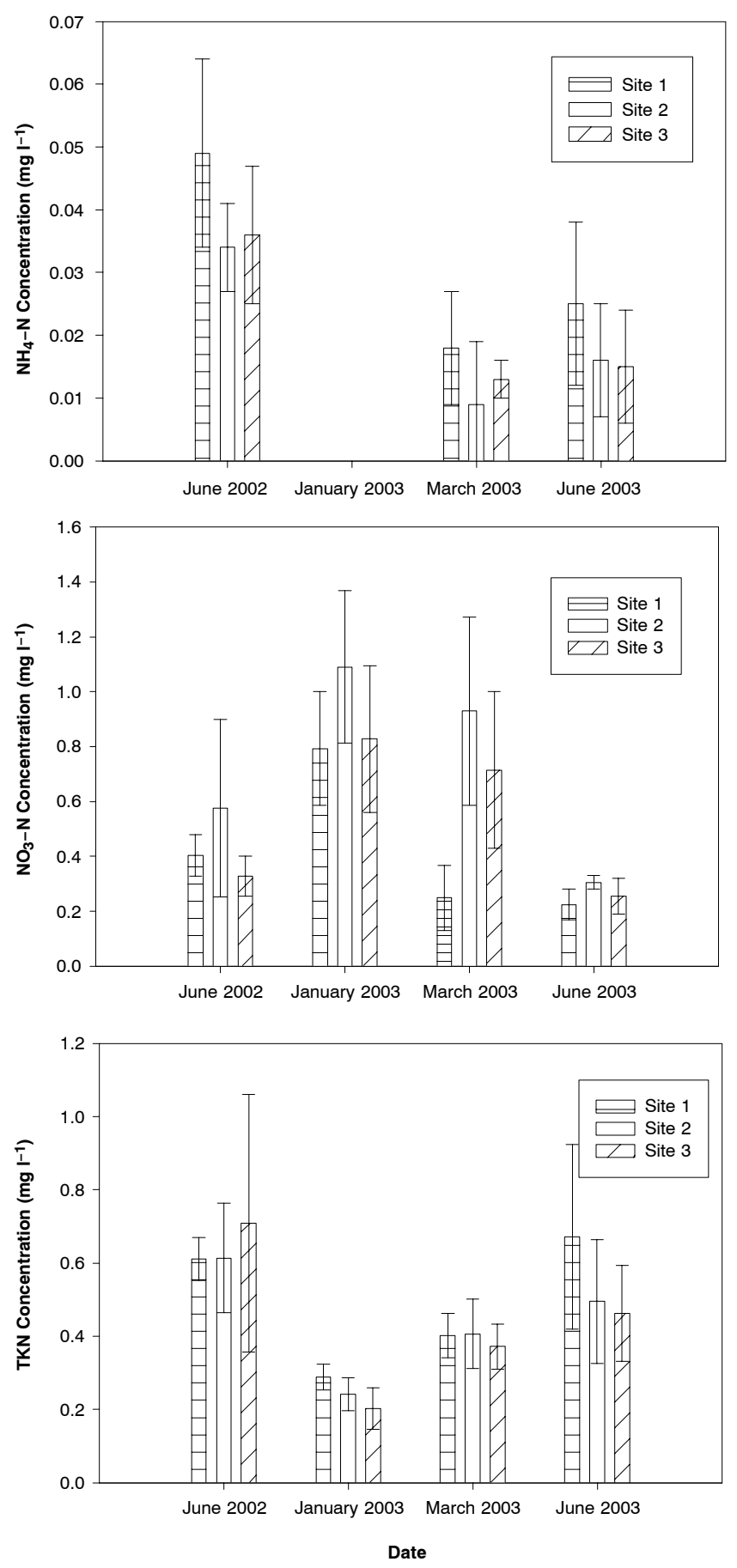

Figure 2. Water quality data showing average (error bars indicate \pm 1 standard deviation) ambient $\mathrm{NH}_{4}-\mathrm{N}, \mathrm{NO}_{3}-\mathrm{N}$, and $\mathrm{TKN}$ concentrations in Moore's Creek during study periods.

during summer (June 2002 and June 2003). Other studies (Nelson et al., 2001) observed a similar pattern of seasonal variation in $\mathrm{NO}_{3}-\mathrm{N}$ concentration in Moore's Creek. Seasonal variation in $\mathrm{NO}_{3}-\mathrm{N}$ concentration can be attributed to various biotic processes, plant uptake, and denitrification in riparian and terrestrial zones (Hubbard and Sheridan, 1983; Lowrance et al., 1995, 2000). A significant spatial difference $(\mathrm{p}=0.003)$ in $\mathrm{NO}_{3}-\mathrm{N}$ concentration existed between study sites. In all the experiments, the $\mathrm{NO}_{3}-\mathrm{N}$ concentration was greater at site 2 compared to sites 1 and 3 .
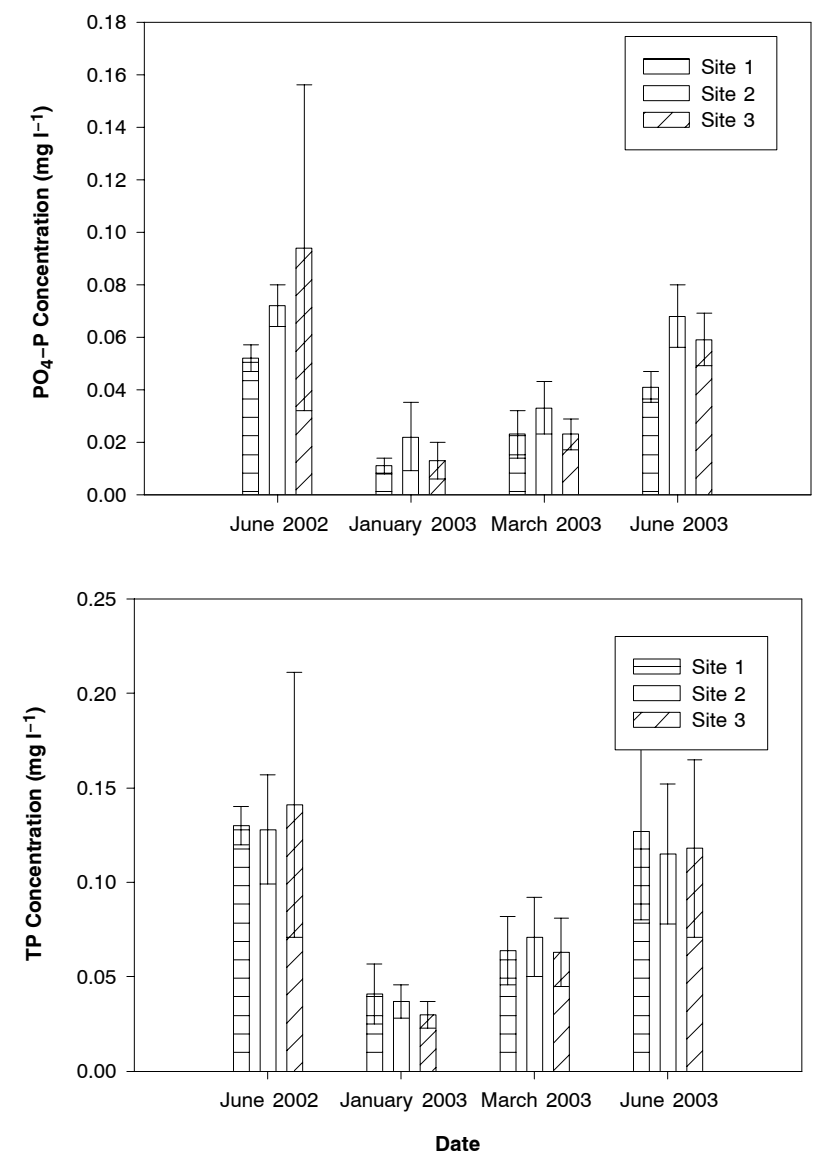

Figure 3. Water quality data showing average ( \pm 1 standard deviation) ambient $\mathrm{PO}_{4}-\mathrm{P}$ and TP concentrations in Moore's Creek during study periods.

A seasonal variation $(\mathrm{p}=0.0001)$ in $\mathrm{TKN}$ concentration was also observed. Average TKN concentration at the three sites ranged between 0.24 and $0.73 \mathrm{mg} \mathrm{L}^{-1}$ (fig. 2). The greatest TKN concentration was observed during high-temperature months (June 2002 and June 2003) compared to the other months. TKN concentrations were statistically similar between the sites in June 2002 and March 2003. However, spatial variation in TKN concentration was observed during January 2003 and June 2003, where the greatest TKN concentration was measured at site 1 and generally decreased farther downstream.

Average $\mathrm{PO}_{4}-\mathrm{P}$ concentrations in Moore's Creek varied between 0.01 and $0.09 \mathrm{mg} \mathrm{L}^{-1}$ (fig. 3). Temporal variation in $\mathrm{PO}_{4}-\mathrm{P}$ concentration was observed, where concentrations were least during spring and winter months (January 2003 and March 2003) and greatest during summer months (June 2002 and June 2003). Measured $\mathrm{PO}_{4}-\mathrm{P}$ concentrations at sites 2 and 3 were significantly greater $(p=0.0001)$ than at site 1 . However, no significant difference in measured $\mathrm{PO}_{4}-\mathrm{P}$ concentrations was found between site 2 and 3. In June 2002, a few water samples at site 3 (only) were collected one day after a storm event, and these samples likely did not truly represent base flow conditions in Moore's Creek. When these samples were not included in the average concentration estimation of $\mathrm{PO}_{4}-\mathrm{P}$, a trend similar to other experiment months was observed.

Average TP concentration at all the three sites varied between 0.03 and $0.14 \mathrm{mg} \mathrm{L}^{-1}$ (fig. 3). These data also 
Table 1. Mean discharge, velocity, depth, and width of the study reaches during different experiments in the 15 -day period at site 1, site 2, and site 3 on Moore's Creek in June 2002, January 2003, March 2003, and June 2003.

\begin{tabular}{|c|c|c|c|c|c|}
\hline $\begin{array}{l}\text { Sampling } \\
\text { Date }\end{array}$ & & $\begin{array}{l}\text { Discharge }[\mathrm{a}] \\
\left(\mathrm{m}^{3} \mathrm{~s}^{-1}\right)\end{array}$ & $\begin{array}{l}\text { Velocity } \\
\left(\mathrm{m} \mathrm{s}^{-1}\right)\end{array}$ & $\begin{array}{c}\text { Water } \\
\text { Depth } \\
\text { (m) }\end{array}$ & $\begin{array}{c}\text { Water } \\
\text { Width } \\
\text { (m) }\end{array}$ \\
\hline \multicolumn{6}{|l|}{ June 2002} \\
\hline 17 June & Site 1 & $7.5 \times 10^{-3}$ & $2.5 \times 10^{-2}$ & $6.7 \times 10^{-2}$ & 4.3 \\
\hline 18 June & Site 2 & $3.7 \times 10^{-3}$ & $2.0 \times 10^{-2}$ & $7.8 \times 10^{-2}$ & 3.4 \\
\hline 19 June & Site 3 & $6.8 \times 10^{-3}$ & $5.3 \times 10^{-2}$ & $3.7 \times 10^{-2}$ & 5.7 \\
\hline \multicolumn{6}{|l|}{ January 2003} \\
\hline 27 Jan. & Site 1 & $8.3 \times 10^{-3}$ & $2.0 \times 10^{-2}$ & $7.4 \times 10^{-2}$ & 5.9 \\
\hline 24 Jan. & Site 2 & $13.0 \times 10^{-3}$ & $12.0 \times 10^{-2}$ & $9.5 \times 10^{-2}$ & 3.0 \\
\hline 25 Jan. & Site 3 & $10.0 \times 10^{-3}$ & $8.0 \times 10^{-2}$ & $6.8 \times 10^{-2}$ & 5.4 \\
\hline \multicolumn{6}{|l|}{ March 2003} \\
\hline 17 Mar. & Site 1 & $18.0 \times 10^{-3}$ & $4.7 \times 10^{-2}$ & $9.2 \times 10^{-2}$ & 5.4 \\
\hline 23 Mar. & Site 2 & $80.0 \times 10^{-3}$ & $22.0 \times 10^{-2}$ & $13 \times 10^{-2}$ & 3.7 \\
\hline 24 Mar. & Site 3 & $42.0 \times 10^{-3}$ & $11.0 \times 10^{-2}$ & $7.4 \times 10^{-2}$ & 7.5 \\
\hline \multicolumn{6}{|l|}{ June 2003} \\
\hline 14 June & Site 1 & $10.0 \times 10^{-3}$ & $6.3 \times 10^{-2}$ & $6.1 \times 10^{-2}$ & 4.8 \\
\hline 15 June & Site 2 & $9.8 \times 10^{-3}$ & $4.2 \times 10^{-2}$ & $10 \times 10^{-2}$ & 3.0 \\
\hline 15 June & Site 3 & $8.7 \times 10^{-3}$ & $5.7 \times 10^{-2}$ & $5.7 \times 10^{-2}$ & 4.9 \\
\hline
\end{tabular}

[a] Discharge variability among sampling sites was due to difference in sampling dates or rainfall occurring between the successive sampling events.

suggested a temporal variation in TP concentration $(\mathrm{p}=$ 0.0001 ), where greater TP concentrations were observed during summer (June 2002 and June 2003) and lower concentrations were observed during winter (January 2003) and spring (March 2003); this trend was similar to that observed with $\mathrm{PO}_{4}-\mathrm{P}$ concentration. There was no consistent trend in measured TP concentrations observed between sites.

\section{Hydrologic and Channel Property of Stream}

Discharge in Moore's Creek ranged between 0.004 and $0.08 \mathrm{~m}^{3} \mathrm{~s}^{-1}$ (table 1) during base flow conditions that existed under experimental conditions. Mean discharge was usually greater in winter (January 2003) and spring (March 2003) and lower in summer (June 2003) at all three sites. Maximum measured discharge was observed at site 2 during the March 2003 experiment. Similarly, average water velocity and depth increased during winter and spring months and decreased during summer months. Similar to discharge, the maximum water velocity was measured at site 2 . However, the maximum average flow width was observed at site 3 in the March 2003 experiment.

\section{LIMITING NUTRIENT}

For all sites, no significant difference in Chl-a production due to treatment effects $(\mathrm{N}, \mathrm{P}$, and $\mathrm{N}+\mathrm{P})$ was observed, indicating that nutrients $(\mathrm{N}$ and $\mathrm{P})$ were not limiting algal growth in any season (fig. 4). Chlorophyll-a content on the artificial growth substrate followed a similar trend between sites during June 2002 and June 2003, where Chl-a content was greater at site 1 compared to sites 2 and $3(\mathrm{p}=0.001)$ (fig. 4). However, Chl-a content was similar among all three sites during January 2003 and March 2003. The spatial differences in incident light on periphytometers due to relative difference in canopy cover at three sites (i.e., width of riparian forest ranging from 0 to $500 \mathrm{~m}$ ) may have caused a variation in Chl-a content between sites during June 2002
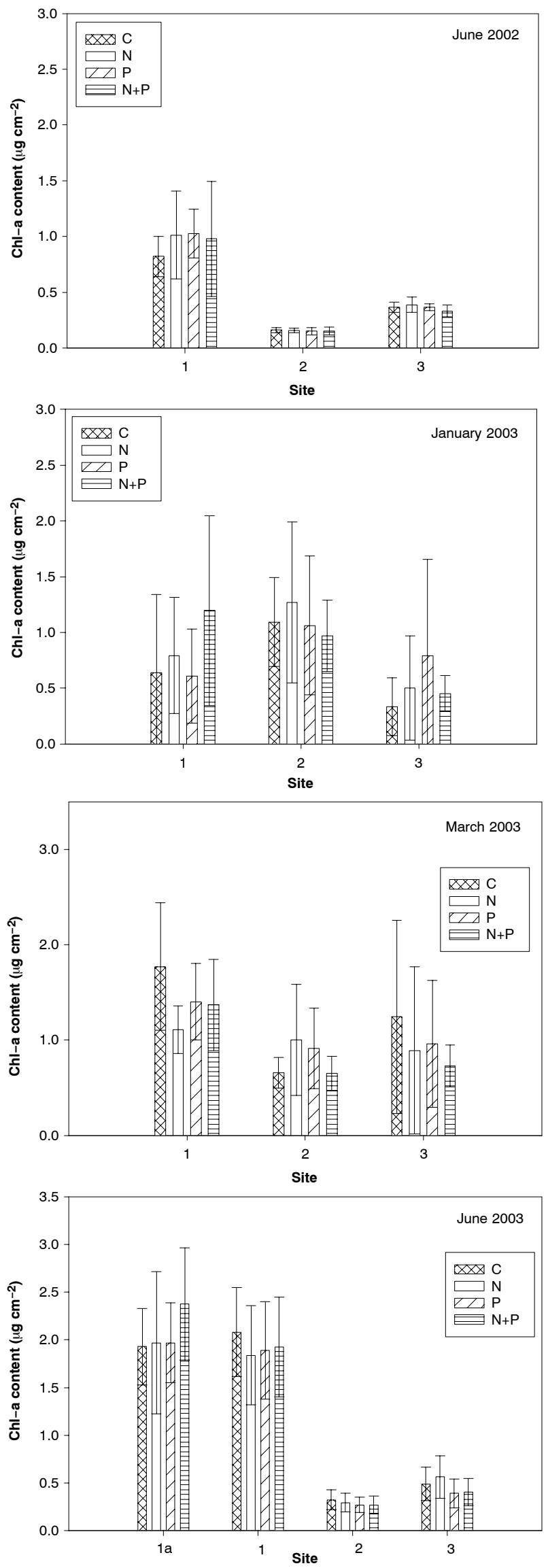

Figure 4. Average (error bars indicate \pm 1 standard deviation) chlorophyll -a content for $\mathrm{C}, \mathrm{N}, \mathrm{P}$, and N+P treatments at Moore's Creek during study periods. 
and June 2003. However, similar Chl-a content between sites during January 2003 and March 2003 may have been due to lack of leaves in the riparian forest, resulting in similar incident light at all the three sites. A temporal variation in light due to changes in canopy cover likely resulted in greater Chla content during winter and spring sampling at sites 2 and 3 . Lack of seasonal difference in the Chl-a content at the most upstream site was likely because light availability was similar across the seasons due to a negligible riparian forest.

To test the hypothesis that light, and not nutrients, was limiting algal production in Moore's Creek, we installed a periphytometer at a site (site 1a) upstream from the site 1 in June 2003. This site was completely devoid of any riparian forest; hence, light limitation due to shading did not occur at this site. Incident light on the periphytometer at each site was measured using an LI-192S quantum sensor (Li-Cor Corp., Lincoln, Neb.) twice a day on two different dates with clear sky conditions between 9:00 a.m. and 12:00 noon and between 4:00 and 6:00 p.m. Average incident light intensities were $1656,450,41$, and $36 \mu \mathrm{mol} \mathrm{s}-1 \mathrm{~m}^{-2}$ at sites $1 \mathrm{a}, 1,2$, and 3 , respectively, showing that average light availability at sites $1 \mathrm{a}$ and 1 was significantly greater than at the other two sites $(p=0.001)$. Chl-a contents from various treatments from this site in comparison with the other sites are shown in figure 4 (June 2003). No significant difference in Chl-a content was observed among treatments at this site, indicating that nutrients were not limiting Chl-a production. In addition, no significant difference in Chl-a content was observed between site 1a and site 1 for all treatments. However, Chl-a contents at sites $1 \mathrm{a}$ and 1 were significantly greater than at sites 2 and 3, indicating that light was limiting Chl-a production at sites 2 and 3 .

The lack of algal growth response to nutrient enrichment was not surprising, because ambient nutrient concentrations in Moore's Creek were generally greater than those that may limit algal productivity. In Ozark streams, $\mathrm{NO}_{3}-\mathrm{N}$ concentrations less than $0.1 \mathrm{mg} \mathrm{L}^{-1}$ often limit algal growth (Lohman et al., 1991); however, $\mathrm{NO}_{3}-\mathrm{N}$ concentrations in Moore's Creek were greater than $0.1 \mathrm{mg} \mathrm{L}^{-1}$, suggesting that $\mathrm{N}$ availability may not be limiting algal growth. Additionally, control treatment $\mathrm{Chl}-\mathrm{a}$ results did not increase with increased ambient $\mathrm{NO}_{3}-\mathrm{N}$ concentration, again indicating that $\mathrm{N}$ was not limiting algal growth. Similarly, $\mathrm{PO}_{4}-\mathrm{P}$ concentrations in Moore's Creek were generally greater than concentrations that may limit algal growth (i.e., $0.01 \mathrm{mg} \mathrm{L}^{-1}$; Newbold, 1992). Additionally, the control treatment Chl-a results did not increase with increased ambient $\mathrm{PO}_{4}-\mathrm{P}$ concentration, again indicating that $\mathrm{PO}_{4}-\mathrm{P}$ was not limiting algal growth. Results from this study indicate that it is very important to maintain a good riparian cover in nutrient-rich headwater streams. If land management practices in such watersheds result in removal of riparian cover, then an increased algal production in the stream can be expected.

\section{SEDIMENT-NUTRIENT INTERACTIONS}

Average sediment exchangeable $\mathrm{P}$ concentration $\left(\mathrm{EPC}_{0}\right)$ ranged between 0.01 and $0.09 \mathrm{mg} \mathrm{L}^{-1}$. Some spatial and temporal variation was observed in sediment $\mathrm{EPC}_{0}$ at the sites. However, spatial patterns across these sites were not distinct among the different seasons, and no clear temporal pattern in sediment $\mathrm{EPC}_{0}$ was observed at sites. A comparison of sediment $\mathrm{EPC}_{0}$ and water column $\mathrm{PO}_{4}-\mathrm{P}$ concentrations suggested that sediments likely released $\mathrm{PO}_{4}-\mathrm{P}$ to the
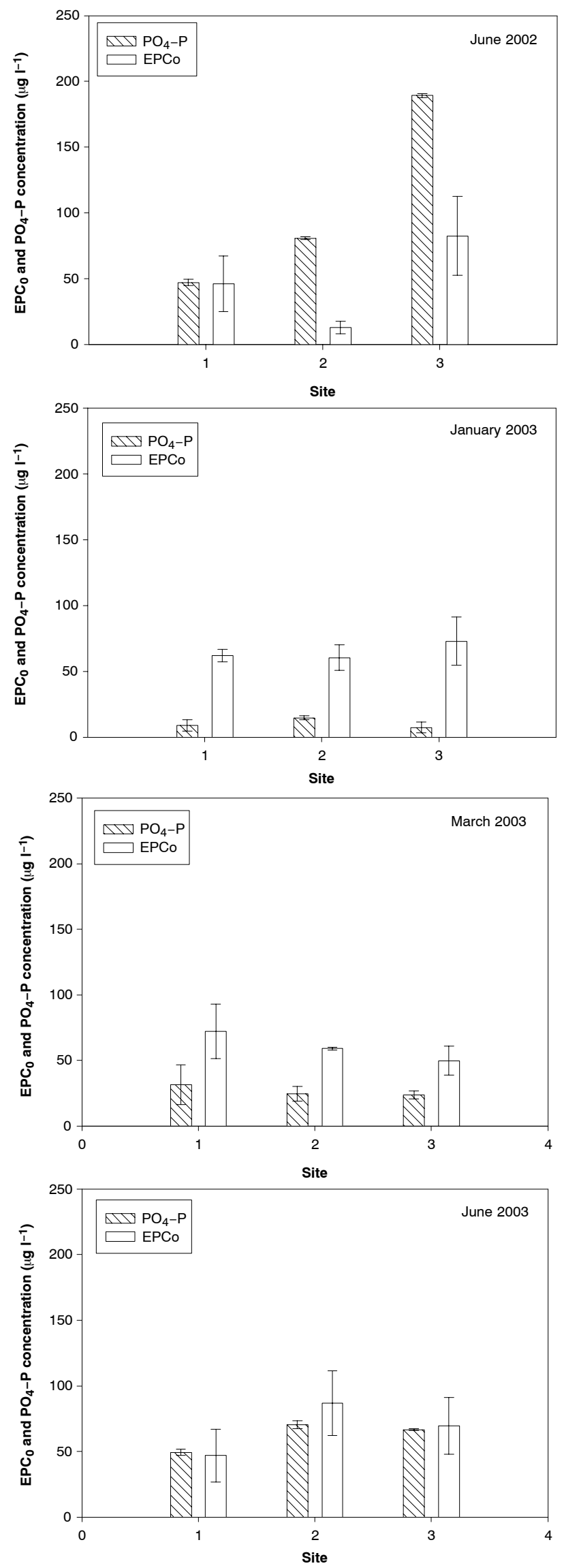

Figure 5. Comparison of estimate average (error bars indicate \pm 1 standard deviation) sediment $\mathrm{EPC}_{0}$ with average ambient water column $\mathrm{PO}_{4}-\mathrm{P}$ concentration in Moore's Creek during study periods. 
Table 2. Estimated mean and standard deviation of Ex-P and PSI of benthic sediments at three experimental reaches of Moore's Creek during June 2002, January 2003, March 2003, and June 2003.

\begin{tabular}{cccccc}
\hline & \multicolumn{2}{c}{ Ex-P } & & \multicolumn{2}{c}{ PSI } \\
& $\left(\mathrm{mg} \mathrm{Pg} \mathrm{k}^{-1}\right.$ dry soil $)$ & & & \\
\cline { 2 - 3 } \cline { 5 - 6 } & Mean & SD & & Mean & SD \\
\hline June 2002 & & & & \\
Site 1 & 0.40 & 0.17 & & 4.15 & 0.70 \\
Site 2 & 0.17 & 0.08 & & 4.33 & 0.32 \\
Site 3 & 0.17 & 0.03 & & 4.27 & 0.54 \\
\hline January 2003 & & & & \\
Site 1 & 0.98 & 1.17 & & 3.94 & 0.38 \\
Site 2 & 0.41 & 0.02 & & 4.03 & 0.66 \\
Site 3 & 0.23 & 0.02 & & 4.56 & 0.60 \\
\hline March 2003 & & & & \\
Site 1 & 0.44 & 0.07 & & 4.99 & 1.05 \\
Site 2 & 0.89 & 0.93 & & 3.22 & 0.14 \\
Site 3 & 0.36 & 0.01 & & 4.73 & 0.33 \\
\hline June 2003 & & & & \\
Site 1 & 0.38 & 0.22 & 4.32 & 0.68 \\
Site 2 & 0.38 & 0.11 & 3.43 & 0.42 \\
Site 3 & 0.36 & 0.17 & 4.19 & 0.16 \\
\hline
\end{tabular}

stream during winter (January 2003) and spring (March 2003) experiments because water column $P$ was less than sediment $\mathrm{EPC}_{0}$ (fig. 5). However, sediments were in equilibrium with water column $\mathrm{P}$ or behaved as a temporary sink of $\mathrm{P}$ during summer (June) (fig. 5). Annual average sediment $\mathrm{EPC}_{0}$ was compared to annual average water column $\mathrm{P}$ to verify how sediment $\mathrm{EPC}_{0}$ and water column $\mathrm{P}$ were related. The results suggested that sediments were likely releasing $\mathrm{P}$ at the most upstream site (site 1), where sediment $\mathrm{EPC}_{0}$ was greater $(\mathrm{p}=0.001)$ than water column $\mathrm{P}$ concentration. However, sediment $\mathrm{EPC}_{0}$ was in equilibrium with water column $\mathrm{P}$ concentration at sites 2 and 3 when all data across each season were considered.

The mean exchangeable $\mathrm{P}(\mathrm{Ex}-\mathrm{P})$ varied between 0.4 and $0.98 \mathrm{mg} \mathrm{kg}^{-1}$ of dry sediment (table 2). These data were consistent with the Ex-P concentration of 0.1 to $0.8 \mathrm{mg} \mathrm{kg}^{-1}$ reported by Haggard et al. (1999). It should be noted that Ex-P is a very conservative estimate of loosely bound $\mathrm{P}$ and should only be used to make relative comparisons among sites and streams. Temporal variation in the amount of Ex-P was observed only at site $3(\mathrm{p}=0.07)$, where it was least during June 2002 (table 2). Spatial variation in Ex-P was only observed during June 2002 (table 2), where it was greatest at site 1 .

The mean P sorption index (PSI) varied between 3.2 and 5.0 in this study (table 2). These values were consistent with the PSI range of 3.5 to 5.5 reported by Haggard et al. (1999). Some temporal and spatial variations in PSI were observed during the experiments. Temporal variation $(\mathrm{p}=0.02)$ for PSI existed only at site 2 (table 2 ), where it was less during spring 2003. However, spatial variability $(p=0.03)$ for PSI was observed only during March 2003, where PSI at site 2 was less than at sites 1 and 3 .

\section{NUTRIENT INJECTION}

In general, no particular spatial or temporal pattern of net uptake length $\left(S_{w}\right)$ and mass transfer coefficient $\left(v_{f}\right)$ for $\mathrm{NH}_{4}-\mathrm{N}$ was observed in this study (table 3 ). $\mathrm{NH}_{4}-\mathrm{N}$ concentrations generally decreased between sampling sites. In all injection experiments, except at site 2 in March 2003,
Table 3. Nutrient uptake lengths $\left(S_{w}\right)$ and mass transfer coefficient $\left(v_{f}\right)$ of $\mathrm{NH}_{4}-\mathrm{N}$, DIN, and $\mathrm{PO}_{4}-\mathrm{P}$ at study sites in Moore's Creek. [a]

\begin{tabular}{|c|c|c|c|c|c|c|}
\hline & \multicolumn{3}{|c|}{$\begin{array}{l}\text { Uptake Length, } \\
S_{w}(\mathrm{~m})\end{array}$} & \multicolumn{3}{|c|}{$\begin{array}{c}\text { Mass Transfer Coefficient, } \\
v_{f}\left(\times 10^{-5} \mathrm{~m} \mathrm{~s}^{-1}\right)\end{array}$} \\
\hline & $\mathrm{NH}_{4}-\mathrm{N}$ & DIN & $\mathrm{PO}_{4}-\mathrm{P}$ & $\mathrm{NH}_{4}-\mathrm{N}$ & DIN & $\mathrm{PO}_{4}-\mathrm{P}$ \\
\hline \multicolumn{7}{|l|}{ June 2002} \\
\hline Site 1 & 118 & $*$ & * & 1.44 & $*$ & $*$ \\
\hline Site 2 & 96 & $*$ & 189 & 1.65 & $*$ & 0.84 \\
\hline Site 3 & 62 & 418 & 93 & 3.17 & 0.48 & 2.13 \\
\hline \multicolumn{7}{|c|}{ January 2003} \\
\hline Site 1 & 18 & $*$ & $*$ & 8.29 & $*$ & $*$ \\
\hline Site 2 & 32 & $*$ & * & 37.7 & $*$ & $*$ \\
\hline Site 3 & 27 & 253 & 334 & 20.2 & 2.19 & 1.66 \\
\hline \multicolumn{7}{|c|}{ March 2003} \\
\hline Site 1 & 87 & 202 & $*$ & 5.10 & 2.10 & $*$ \\
\hline Site 2 & $*$ & $*$ & 305 & * & $*$ & 9.85 \\
\hline Site 3 & 197 & $*$ & 118 & 4.16 & $*$ & 6.93 \\
\hline \multicolumn{7}{|l|}{ June 2003} \\
\hline Site 1 & 94 & $*$ & 36 & 4.13 & $*$ & 10.6 \\
\hline Site 2 & 98 & 647 & 309 & 4.34 & 0.66 & 1.38 \\
\hline Site 3 & 55 & 468 & $*$ & 5.93 & 0.70 & $*$ \\
\hline
\end{tabular}

the slope of the regression line used for estimating $S_{w}$ was significant $(\mathrm{p}=0.07) . S_{w}$ for $\mathrm{NH}_{4}-\mathrm{N}$ in the injection experiments ranged between 18 and $197 \mathrm{~m}$ and was consistent with a range of 32 to $900 \mathrm{~m}$ reported in the literature (e.g., Marti and Sabater, 1996; Butturini and Sabater, 1998; Haggard et al., 2001; Simon and Benfield, 2002). The shortest $S_{w}$ for $\mathrm{NH}_{4}-\mathrm{N}$ was observed in winter (January 2003). The range of $v_{f}$ for $\mathrm{NH}_{4}-\mathrm{N}$ varied between $1.4 \times 10^{-5}$ and $3.8 \times 10^{-4} \mathrm{~m} \mathrm{~s}^{-1}$ across all sites and was similar to the range reported by Haggard et al. (2001) $\left(1.9 \times 10^{-5}\right.$ to $9.6 \times 10^{-5} \mathrm{~m} \mathrm{~s}^{-1}$, unpublished data), Webster et al. (2003) $\left(3.4 \times 10^{-5}\right.$ to $\left.6.9 \times 10^{-4} \mathrm{~m} \mathrm{~s}^{-1}\right)$, and Hall et al. $(2002)\left(1.35 \times 10^{-5}\right.$ to $\left.1.21 \times 10^{-4} \mathrm{~m} \mathrm{~s}^{-1}\right)$. The smallest $(\mathrm{p}=0.007) v_{f}$ for $\mathrm{NH}_{4}-\mathrm{N}$ was observed during June 2002 across all sites, and the greatest $v_{f}$ was observed during January 2003. The shortest $(\mathrm{p}=0.007) S_{w}$ for $\mathrm{NH}_{4}-\mathrm{N}$ coincided with the greatest $v_{f}$ for $\mathrm{NH}_{4}-\mathrm{N}$.

Concentrations of $\mathrm{NO}_{3}-\mathrm{N}$ increased downstream of the injection point during all the experiments, resulting in no retention of $\mathrm{NO}_{3}-\mathrm{N}$. The co-injection of $\mathrm{NH}_{4}-\mathrm{N}$ and $\mathrm{NO}_{3}-\mathrm{N}$ might have resulted in increased $\mathrm{NO}_{3}-\mathrm{N}$ concentration downstream of injection because of nitrification of injected $\mathrm{NH}_{4}-\mathrm{N}$. Measured increase in $\mathrm{NO}_{3}-\mathrm{N}$ concentrations along with a decrease in $\mathrm{NH}_{4}-\mathrm{N}$ concentrations was used to calculate potential net nitrification rates for injected $\mathrm{NH}_{4}-\mathrm{N}$ for each experiment. On average, approximately $40 \%$ of the injected $\mathrm{NH}_{4}-\mathrm{N}$ was estimated to be potentially nitrified during the experiment. Results of this study indicate that Moore's Creek may not be assimilating $\mathrm{NO}_{3}-\mathrm{N}$, especially in the presence of $\mathrm{NH}_{4}-\mathrm{N}$. Assimilation may be mostly caused by nitrification; consequently, $\mathrm{NO}_{3}-\mathrm{N}$ is basically flushed downstream through the water column without any significant removal. Royer et al. (2004) also reported that in agricultural headwater streams, most $\mathrm{NO}_{3}-\mathrm{N}$ was exported to downstream water bodies at annual scale.

Dissolved inorganic $\mathrm{N}$ (DIN) was estimated as the sum of $\mathrm{NO}_{3}-\mathrm{N}$ and $\mathrm{NH}_{4}-\mathrm{N}$, and the downstream gradient during injections was used to calculate $S_{w}$ for DIN. $S_{w}$ calculations for DIN were significant for 5 out of 12 injections, ranging between 202 and $647 \mathrm{~m}$ (table 3). Estimated $S_{w}$ for DIN was 
longest among all the estimated uptake lengths during all the injections, showing that the DIN was not assimilated by the stream as efficiently as $\mathrm{PO}_{4}-\mathrm{P}$.

Concentrations of $\mathrm{PO}_{4}-\mathrm{P}$ generally decreased downstream of the injection point at all the three sites. In 7 out of 12 injections, calculated $S_{w}$ for $\mathrm{PO}_{4}-\mathrm{P}$ was significant $(\mathrm{p}=$ 0.05). $S_{w}$ for $\mathrm{PO}_{4}-\mathrm{P}$ in the injection experiments ranged between 36 and $309 \mathrm{~m}$ (table 3 ) and was consistent with the range of 5 to $900 \mathrm{~m}$ reported by several other studies (e.g., Marti and Sabater, 1996; Haggard et al., 2001). Generally, there were no consistent spatial or temporal patterns in $S_{w}$ for $\mathrm{PO}_{4}-\mathrm{P}$ at any sites or during any season. Estimated $v_{f}$ for $\mathrm{PO}_{4}-\mathrm{P}$ varied from $8.4 \times 10^{-6}$ to $1.1 \times 10^{-4}$ $\mathrm{m} \mathrm{s}^{-1}$ across all the sites and was comparable to values observed in other investigations: $7.2 \times 10^{-5}$ to $1.7 \times 10^{-4} \mathrm{~m}$ $\mathrm{s}^{-1}$ (Davis and Minshall, 1999) and $3.2 \times 10^{-5}$ to $1.93 \times 10^{-4}$ $\mathrm{m} \mathrm{s}^{-1}$ (Hall et al., 2002). Similar to $\mathrm{NH}_{4}-\mathrm{N}$, the shortest $S_{w}$ for $\mathrm{PO}_{4}-\mathrm{P}$ coincided with the greatest $v_{f}$. Results from this study indicate that even in nutrient-rich streams, $\mathrm{PO}_{4}-\mathrm{P}$ is assimilated within the stream segment. Any increased $\mathrm{PO}_{4}-\mathrm{P}$ load from the watershed may likely be assimilated, to some extent.

\section{Conclusions}

Results indicated that nutrients were not limiting algal growth in Moore's Creek; light was likely the limiting factor. The watershed management decisions to protect water quality in nutrient-rich streams must consider riparian area management, as a loss of riparian shading may result in significant algal production in the stream. The sediment-nutrient interactions data suggested that sediments were playing an active role in controlling water column $\mathrm{P}$ concentrations; benthic sediments likely released $\mathrm{PO}_{4}-\mathrm{P}$ to the overlying water column during winter and spring, and were either in equilibrium with water column $\mathrm{P}$ or likely behaved as a temporary sink in summer by adsorbing water column $\mathrm{PO}_{4}-\mathrm{P}$. A distinct temporal variability in sediment equilibrium $\mathrm{P}$ concentration also indicated that sorption of $\mathrm{P}$ by benthic sediment may not strictly be an abiotic process. Increased microbial activities in benthic sediments may play an important role in reducing water column $\mathrm{P}$ concentrations in summer. Some spatial and temporal variability in the measured $\mathrm{P}$ sorption index and exchangeable $\mathrm{P}$ were observed.

Short-term nutrient injection results indicated that $\mathrm{NH}_{4}-\mathrm{N}$ was efficiently assimilated in the stream, apparently from nitrification. However, $\mathrm{NO}_{3}-\mathrm{N}$ was not assimilated, indicating that agricultural headwater streams may be a significant source of downstream $\mathrm{NO}_{3}-\mathrm{N}$ transport. Injected $\mathrm{PO}_{4}-\mathrm{P}$ was assimilated in the stream, indicating that even nutrient-rich streams may continue to assimilate increased loads of $\mathrm{PO}_{4}-\mathrm{P}$ and alter the timing and magnitude of downstream transport of $\mathrm{P}$.

\section{ACKNOWLEDGEMENTS}

Funding for this study was provided by U.S. Environment Protection Agency and the Arkansas Natural Resources Commission. We are thankful to Dr. M. Nelson and his staff for analyzing water samples. We would like to extend our sincere appreciation to all the land owners for providing us access to the streams on their property. Several graduate and undergraduate students at the University of Arkansas also provided help with the field work. Comments provided by Dr. Thomas Franti and three anonymous reviewers greatly improved the initial versions of the manuscript.

\section{REFERENCES}

Allan, J. D. 1995. Stream Ecology: Structure and Function of Running Waters. London, U.K.: Chapman and Hall.

APHA. 1998. Standard Methods for the Examination of Water and Wastewater. Washington, D.C.: American Public Health Association.

Bache, B. W., and E. G. Williams. 1971. A phosphate sorption index for soils. J. Soil Sci. 22(3): 289-301.

Brussock, P. P., A. V. Brown, and J. C. Dixon. 1985. Channel form and stream ecosystem models. Water Resources Bull. 21(5): 859-866.

Butturini, A., and F. Sabater. 1998. Ammonium and phosphate retention in a Mediterranean stream: Hydrological versus temperature control. Canadian J. Fisheries and Aquatic Sci. 55(8): 1938-1945.

Cotter, A. 2002. Critical Evaluation of TMDL data requirements for agricultural watersheds. MS thesis. Fayetteville, Ark.: University of Arkansas.

D’Angelo, D. J., J. R. Webster, and E. F. Benfield. 1991. Mechanisms of stream phosphorus retention: An experimental study. J. North American Benth. Soc. 10(3): 225-237.

Davis, J. C., and G. W. Minshall. 1999. Nitrogen and phosphorus uptake in two Idaho (USA) headwater wilderness streams. Oecologia 119(2): 247-255.

Edwards, D. R., T. C. Daniel, H. D. Scott, J. F. Murdoch, M. J. Habiger, and H. M. Burks. 1996. Stream quality impact of best management practices in a northwest Arkansas basin. $J$. American Water Res. Assoc. 32(3): 499-509.

Elwood, J. W., J. D. Newbold, A. F. Trimble, and R. W. Starke. 1981. The limiting role of phosphorus in a woodland stream ecosystem: Effects of P enrichment on leaf decomposition and primary producers. Ecology 62(1): 146-158.

Elwood, J. W., J. D. Newbold, R. V. O'Neill, and W. Winkle. 1983. Resource spiraling: An operational paradigm for analyzing lotic ecosystems. In The Dynamics of Lotic Ecosystem, 3-27. Ann Arbor, Mich.: Ann Arbor Science.

Grimm, N. B. 1987. Nitrogen dynamics during succession in a desert stream. Ecology 68(5): 1157-1170.

Grimm, N. B., and S. G. Fisher. 1986. Nitrogen limitation in a Sonoran Desert stream. J. North American Benth. Soc. 5(1): $2-15$.

Haggard, B. E., E. H. Stanley, and R. Hyler. 1999. Sediment-phosphorus interactions in three north-central Oklahoma streams. Trans. ASAE 42(6): 1709-1714.

Haggard, B. E., D. E. Storm, R. D. Tejral, Y. A. Popova, V. G. Keyworth, and E. H. Stanley. 2001. Stream nutrient retention and limitation in three northeastern Oklahoma agricultural catchments. Trans. ASAE 44(3): 597-605.

Hall, R. O. Jr., E. S. Bernhardt, and G. E. Likens. 2002. Relating nutrient uptake with transient storage in forested mountain streams. Limnology and Oceanography 47(1): 255-265.

Hauer, F. R., and G. A. Lamberti. 1996. Methods in Stream Ecology. San Diego, Cal.: Academic Press.

House, W. A., F. H. Denison, and P. D. Armitage. 1995. Comparison of the uptake of inorganic phosphorus to suspended and streambed sediment. Water Resources 29(3): 767-779.

Hubbard, R. K., and J. M. Sheridan. 1983. Water and nitrate-nitrogen losses from a small, upland, coastal plain watershed. J. Environ. Qual. 12(2): 291-295.

Klotz, R. L. 1988. Sediment control of soluble reactive phosphorus in Hoxie Gorge Creek, New York. Canadian J. Fish and Aquatic Sciences 45(11): 2026-2034. 
Lock, M. A., T. E. Ford, M. A. J. Hullar, M. Kaufman, J. R. Vestal, G. S. Volk, and R. M. Ventullo. 1990. Phosphorus limitation in an arctic river biofilm: A whole-ecosystem experiment. Water Resources 24(12): 1545-1549.

Lohman, K., J. R. Jones, and C. B. Daniel. 1991. Experimental evidence for nitrogen limitation in a northern Ozark stream. $J$. North American Benth. Soc. 10(1): 14-23.

Lowrance, R., G. Vellidis, and R. K. Hubbard. 1995. Denitrification in a restored riparian forest wetland. J. Environ. Qual. 24(5): 808-815.

Lowrance, R., R. K. Hubbard, and R. G. Williams. 2000. Effects of a managed three-zone riparian buffer system on shallow groundwater quality in the southeastern coastal plain. J. Soil and Water Cons. 55(2): 212-220.

Macrae, M. L., M. C. English, S. L. Schiff, and M. A. Stone. 2003. Phosphate retention in an agricultural stream using experimental additions of phosphate. Hydrological Processes 17(18): 3649-3663.

Marti, E., and F. Sabater. 1996. High variability in temporal and spatial nutrient retention in Mediterranean streams. Ecology 77(3): 854-869.

Matlock, M. D., M. E. Matlock, D. E. Storm, M. D. Smolen, and W. J. Henley. 1998. Limiting nutrient determination in lotic ecosystems using a quantitative nutrient enrichment periphytometer. J. American Water Res. Assoc. 34(5): 1141-1147.

Meyer, J. L. 1979. The role of sediments and bryophytes in phosphorus dynamics in a headwater stream ecosystem. Limnology and Ocenography 24(2): 365-376.

Meyer, J. L., and G. E. Likens. 1979. Transport and transformation of phosphorus in a forested stream ecosystem. Ecology 60(6): 1255-1269.

Meyer, J. L., M. J. Paul, and W. K. Taulbee. 1999. Nutrient uptake in streams along a gradient of watershed land use. Bull. North American Benth. Soc. 16(1): 376-380.

Morris, D. P., and W. M. Lewis Jr. 1988. Phytoplankton nutrient limitation in Colorado mountain lakes. Freshwater Biol. 20(3): 315-327.

Nelson, M. A., W. L. Cash, and K. F. Steele. 2001. Determination of nutrient loads in upper Moore's Creek 2000. Report by Arkansas Water Resources Center. Fayetteville, Ark.: University of Arkansas.

Newbold, J. D. 1992. Cycles and spirals of nutrients. In The Rivers Handbook, Vol. 1: 379-408. P. Calow and G. E. Petts, eds. Oxford, U.K.: Blackwell Scientific.
Newbold, J. D., J. W. Elwood, R. V. O’Neill, and A. L. Sheldon. 1983. Phosphorus dynamics in woodland stream ecosystems: A study of nutrient spiraling. Ecology 64(5): 1249-1265.

Redfield, A. C. 1958. The biological control of chemical factors in the environment. American Scientist 46(3): 205-221.

Royer, T. V., J. L. Tank, and M. B. David. 2004. Transport and fate of nitrate in headwater agricultural streams in Illinois. J. Environ. Qual. 33(4): 1296-1304.

Ruttenburg, K. C. 1992. Development of sequential extraction method of different forms of phosphorus in marine sediments. Limnology and Oceanography 37(7): 1460-1482.

Sharpley, A. N., S. C. Chapra, R. Wedepohl, T. C. Daniels, and K. R. Reddy. 1994. Managing agricultural phosphorus for protection of surface water: issues and options. J. Environ. Quality 23(3): 437-451.

Sharpley, A. N., R. W. McDowell, and P. J. A. Kleinman. 2001. Phosphorus loss from land and water: Integrating agricultural and environmental management. Plant and Soil 237(2): 287-307.

Sharpley, A. N., P. J. A. Kleinman, R. W. McDowell, M. Gitau, and R. B. Bryant. 2002. Modeling phosphorus transport in agricultural watersheds: Processes and possibilities. J. Soil and Water Cons. 57(6): 425-439.

Sheskin, D. J. 2000. Parametric and Nonparametric Statistical Procedures. 2nd ed. Boca Raton, Fla.: Chapman and Hall/CRC.

Simon, S. K., and E. F. Benfield. 2002. Ammonium retention and whole-stream metabolism in cave streams. Hydrobiologia 482: 31-39.

Stream Solute Workshop. 1990. Concepts and methods for assessing solute dynamics in stream ecosystems. J. North American Benth. Soc. 9(2): 95-119.

Vendrell, P. F., M. A. Nelson, L. W. Cash, K. F. Steele, K. A. Teague, and D. R. Edwards. 1997. Nutrient transport by streams in the Lincoln Lake basin. In Proc. Arkansas Water Resources Center Annual Research Conference, 45-51. Fayetteville, Ark.: University of Arkansas.

Webster, J. R., P. J. Mulholland, J. L. Tank, H. M. Valett, W. K. Dodds, B. J. Peterson, W. B. Bowden, C. N. Dahm, S. Findlay, S. V. Gregory, N. B. Grimm, S. K. Hamilton, S. L. Johnson, E. Marti, W. H. McDowell, J. L. Meyer, D. D. Morrall, S. A. Thomas, and W. M. Wollheim. 2003. Factors affecting ammonium uptake in streams: An inter-biome perspective. Freshwater Biol. 48(8): 1329-1352.

Wold, A. P., and A. E. Hershey. 1999. Spatial and temporal variability of nutrient limitation in six north shore tributaries of Lake Superior. J. North American Benth. Soc. 18(1): 2-14. 